\title{
Effectiveness of Selective Chemical Treatments on Concentrating Magnetic Minerals of Samples from a Nickel-Ore Peridotite Mantle
}

\author{
Maria de Fátima F. Lelis ${ }^{a, \#}$, Cláudia M. Gonçalves ${ }^{a}$, José D. Fabris ${ }^{*, a}$, Wagner N. Mussel ${ }^{a}$ \\ and William A. Pacheco Serrano \\ ${ }^{a}$ Departamento de Química, ICEx, Universidade Federal de Minas Gerais, Campus Pampulha, 31270-901 Belo \\ Horizonte - MG, Brazil \\ ${ }^{b}$ Departamiento de Fisica, UPTC, 1094 Tunja, Boyacá, Colombia
}

\begin{abstract}
Frações magnéticas de duas amostras coletadas a $5 \mathrm{~m}$ e $52 \mathrm{~m}$ de profundidade, a partir do topo de um manto de intemperismo desenvolvido sobre periodito, da área de mineração de níquel em Cerro Matoso (7 54' 31'” N 75³3' 23”' O), Departamento de Córdoba, Colômbia, contêm minerais magnéticos e não magnéticos, intimamente associados. Frações magnéticas, posteriormente concentradas por tratamentos químicos seletivos com $\mathrm{NaOH} 5 \mathrm{~mol} \mathrm{~L}^{-1}$, para remover silicatos, e com uma mistura citrato - bicarbonato - ditionito (CBD), para remover óxidos de ferro não magnéticos, foram analisadas por difratometria de raios X, espectroscopia Mössbauer à temperatura do ambiente, magnetização de saturação, microscopias ótica e eletrônica por varredura e espectroscopia de energia dispersa, para se obter uma descrição detalhada das fases magnéticas presentes. Os tratamentos químicos foram efetivos na concentração dos óxidos de ferro, de tal sorte a permitir melhores resultados da análise mineralógica do minério de níquel. Os resultados Mössbauer revelaram que o tratamento com $\mathrm{NaOH}$ removeu silicatos e cromita e que a mistura CBD solubilizou seletivamente hematita, goethita e magnetita não estequiométrica, parcialmente oxidada.
\end{abstract}

Two magnetic samples, collected at $5 \mathrm{~m}$ and $52 \mathrm{~m}$ from the top of a weathering mantle developing on peridotite, from the Cerro Matoso ( $7^{\circ} 54^{\prime} 31^{\prime \prime} \mathrm{N} 75^{\circ} 33^{\prime} 23^{\prime \prime} \mathrm{W}$ ) mining area for nickel, Department of Cordoba, Colombia, were submitted to magnetic separation with a hand magnet in the laboratory. The so concentrated samples were found to contain intimately associated magnetic and non-magnetic minerals. The magnetic phases were further concentrated by selective chemical treatments with $5 \mathrm{~mol} \mathrm{~L}^{-1} \mathrm{NaOH}$ to remove silicates, and with a mixture citrate - bicarbonate - dithionite, to remove non-magnetic iron oxides. Powder X-ray diffractometry, RT Mössbauer spectroscopy, saturation magnetization measurements, scanning electron microscopy, energy dispersive spectroscopy and optical microscopy analyses were used to give a mineralogical description of the magnetic phases. The chemical treatments were effective on concentrating iron oxides so to improve the mineralogical analysis of this nickel ore. Mössbauer analysis revealed that $\mathrm{NaOH}$ selectively removed silicates and chromite from samples, whereas CBD dissolved hematite, goethite, and partially oxidized non-stoichiometric magnetite.

Keywords: Mössbauer spectroscopy, magnetization, $\mathrm{NaOH}$-treatment, CBD-treatment, iron oxide, spinel

\section{Introduction}

The identification and quantification of most ironbearing soil minerals, particularly iron oxides, by Mössbauer spectroscopy are in some cases difficult for reasons that include: (i) complex mineral assemblages, (ii)

* e-mail: jdfabris@ufmg.br

* Permanent address: Departamento de Química, Universidade Federal do Espírito Santo, 29060-900 Vitória, ES, Brazil. E-mail: mfflelis@cce.ufes.br inhomogeneous chemical composition of minerals, (iii) occurrence of minerals in strongly cemented multiphase grains e (iv) the often low concentration of iron oxides in most samples. The commonly found iron oxides in soils, namely hematite (ideal formula, $\alpha \mathrm{Fe}_{2} \mathrm{O}_{3}$ ), goethite $(\alpha \mathrm{FeOOH})$, ilmenite $\left(\mathrm{FeTiO}_{3}\right)$, maghemite $\left(\gamma \mathrm{Fe}_{2} \mathrm{O}_{3}\right)$ and magnetite $\left(\mathrm{Fe}_{3} \mathrm{O}_{4}\right)$ often coexist with silicate minerals. In such a circumstance, corresponding Mössbauer spectra are exceptionally complex and hyperfine parameters due to each mineralogical phase may not be safely separated by 
routine numerical analysis. Physical extraction methods and selective chemical dissolution are useful laboratory procedures in sample preparation that help improve the mineralogical analysis of soil samples.

Cornell and Schwertmann ${ }^{1}$ provide a relatively recent review on differential dissolution methods. Two main laboratory procedures are commonly used to prepare samples destined to the chemical and physical characterization of iron oxides in soils. The first one is based on the application of chemical extractors that selectively remove either in part or totally certain groups of minerals. Two classical treatments are widely used on geosamples preparation in the laboratory: the mixture citrate-bicarbonate-dithionite (CBD), to selectively remove free diamagnetic iron oxides, ${ }^{2}$ and boiling $5 \mathrm{~mol} \mathrm{~L}^{-1}$ $\mathrm{NaOH},{ }^{3,4}$ to selectively concentrate iron oxides in soil samples. ${ }^{5}$ The second group of laboratory methods includes physical separation commonly used in clay mineral analysis, including those based on particle size, such as sieving or centrifugation, ${ }^{6}$ or on magnetic properties, such as high-gradient magnetic separation. ${ }^{7,8}$

The mode of action of these chemical agents is scarcely known, and dissolution methods used in works on soil materials are largely empirical. ${ }^{9}$ Different iron oxides or samples of a given iron oxide from distinct origins tend to respond differently to CBD treatment. ${ }^{10,11} \mathrm{CBD}$ preferentially removes pedogenic maghemite and leaves lithogenic magnetite unaffected. ${ }^{12}$ CBD is based on the reductive chemical action of dithionite and on the $\mathrm{Fe}^{2+}$ chelating ability of citrate. Bicarbonate is used to buffer the medium during reaction. Differential removal of hematite with CBD can be used to selectively concentrate magnetite of soil samples. ${ }^{13}$ Unfortunately, interpreting the CBD extraction may be not a straightforward procedure, as in some cases it tends to attack very effectively small grains irrespective of the mineral group. ${ }^{14}$

If iron oxides do occur in relatively low concentrations their identification may be further difficult. The treatment with hot $5 \mathrm{~mol} \mathrm{~L}^{-1} \mathrm{NaOH}$ is often used to selectively remove silicates and concentrate iron oxides.

In the present work, the two set of chemical treatments, one with $\mathrm{CBD}$, and other with $5 \mathrm{~mol} \mathrm{~L}^{-1} \mathrm{NaOH}$, were used in an attempt to verify their effectiveness on the selective concentration of magnetic iron oxides of ore samples from the nickel mine of Cerro Matoso, Colombia, firstly by concentrating iron oxides, with $\mathrm{NaOH}$ treatment, and then by concentrating magnetic minerals of the iron oxide-rich fraction, by removing non-magnetic species with CBD. It is a matter of getting answer for a main question: do the two classical dissolution attacks act on this ore material similarly as they do on synthetic or known geological samples from other origins? If yes, these chemical procedures can eventually be considered in larger industrial scales on an economically based production of materials focused in magnetic iron oxides from such an ore.

\section{Experimental}

Two samples, a purple hard material (hereinafter, CVE) and a black saprolite (SPN), were collected, respectively, at $5 \mathrm{~m}$ and $52 \mathrm{~m}$ deep from a weathering mantle developing on peridotite, found in the mining area for nickel ${ }^{15}$ of Cerro Matoso ( $7^{\circ} 54^{\prime} 31^{\prime \prime} \mathrm{N} 75^{\circ} 33^{\prime} 23^{\prime \prime} \mathrm{W}$ ), Department of Cordoba, Colombia. The samples were ball-milled and corresponding magnetic fractions were separated with a hand magnet. Each of these magnetic fractions was divided into three sets of sub-samples. The first set was attacked with $5 \mathrm{~mol} \mathrm{~L}^{-1} \mathrm{NaOH}$ at $90^{\circ} \mathrm{C}$ for 2 hours. The second one was five-fold treated with $\mathrm{CBD}$ at $90^{\circ} \mathrm{C}$ for $30 \mathrm{~min}$. The third set of sub-samples was treated with $5 \mathrm{~mol} \mathrm{~L}^{-1} \mathrm{NaOH}$ followed by five sequential CBD extractions at $90{ }^{\circ} \mathrm{C}$ for 30 min each (Table 1).

Table 1. Sample description and saturation magnetization $(\sigma)$ mesurements

\begin{tabular}{llc}
\hline Samples & Description & $\sigma / \mathrm{J} \mathrm{kg}^{-1} \mathrm{~T}^{-1}$ \\
\hline CVE (a) & whole sample & 13.8 \\
CVE (b) & magnetic fraction & 60.8 \\
CVE (c) & five successive extractions with CBD & 81.3 \\
CVE (d) & NaOH 5 mol L-1 concentration treatment & 69.5 \\
CVE (e) & treated with NaOH and then whit CBD & 84.4 \\
SPN (a) & whole sample & 45.1 \\
SPN (b) & magnetic fraction & 68.5 \\
SPN (c) & five successive extractions with CBD & 79.2 \\
SPN (d) & NaOH 5 mol L-1 concentration treatment & 85.8 \\
SPN (e) & treated with NaOH and then whit CBD & 86.4 \\
\hline
\end{tabular}

Before any treatment their magnetic concentrates and chemically treated samples were analyzed by XRD, with a Rigaku Geigerflex diffractometer equipped with a graphite, diffracted beam monochromator, using $\mathrm{Cu}(\mathrm{K} \alpha)$ radiation ( $\mathrm{NaCl}$ was used as internal standard), by Mössbauer spectroscopy with data collected at room temperature in a constant acceleration transmission set up with a ${ }^{57} \mathrm{Co} / \mathrm{Rh}$ source, and by scanning electron microscopy in a Jeol JXA X 900RL WD/ED microscope with an Energy Dispersive Spectrometer (EDS) module, under $15 \mathrm{keV}$ and $1 \mathrm{~mm}$-beam width. Formulae were allocate with the program FORMAL, available at http://qui.ufmg.br/ Moss, based on the algorithm already described. ${ }^{16}$ The morphology was determined by scanning electron micrography (Jeol JSM840 A). Saturation magnetization measurements were performed with a portable soil magnetometer. ${ }^{17}$ 


\section{Results and Discussion}

CVE and SPN samples each have a distinct mineralogical composition, but they responded very similarly to the chemical treatments. Photomicrographs, XRD patterns, and Mössbauer spectroscopy of magnetic fractions from the CVE and SPN samples indicate that they have distinguishable mineralogy, as following:

\section{CVE sample}

The in nature CVE sample is red and strongly magnetic as it can be deduced from its attraction to a hand magnet. Typical morphologies of the particles are visualized by SEM (Figure 1). The main spinel phases were also identified by optical microscopy. The analyses also indicate that the porous magnetite particles underwent some alteration process. At least one XRD pattern (Figure 2a) reveals that hematite, goethite, silicate minerals, and iron spinel are present. Mössbauer spectroscopy (Figure 3a) and fitted parameters (Table 2) identifies the spinels as being magnetite and chromite $\left(\mathrm{FeCr}_{2} \mathrm{O}_{4}\right)$. Results for the CVE magnetic separate indicate that some martitization, meaning an alteration pathway involving some stage of transformation of magnetite to hematite, had occurred. Its Mössbauer spectrum (Figure $3 \mathrm{~b}$ ) and corresponding hyperfine parameters (Table 2) reveal that the $\left\{\mathrm{Fe}^{3+/ 2+}\right\} /$ $\left[\mathrm{Fe}^{3+}\right]=0.94$ ratio $(\{\}$ and [] mean octahedral and tetrahedral sites, respectively, and $\otimes=$ vacancy) is significantly different from the expected $\sim 1.88$ value for stoichiometric magnetite, also evidencing that oxidation took place. The corresponding averaged chemical formulae for iron oxide spinels of the CVE sample can be derived from EDS data:

$\mathrm{Fe}_{2.38}^{3+} \mathrm{Fe}_{0.44}^{2+} \mathrm{Ni}_{0.02} \otimes_{0.16} \mathrm{O}_{4}$

The XRD pattern of the CVE magnetic separate (Figure $2 \mathrm{~b}$ ) indicates an increase of the iron spinel reflections along

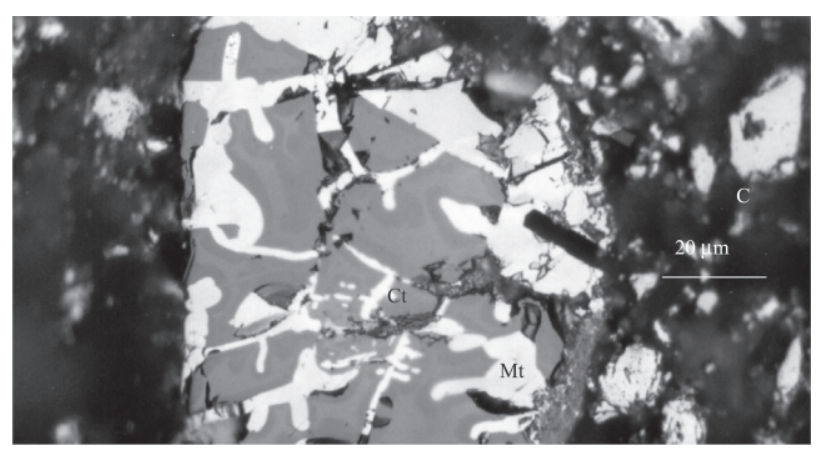

Figure 1. Electron micrograph of the magnetic fraction from the CVE sample $\mathrm{Mt}=$ magnetite; $\mathrm{Ct}=$ chromite . with relatively few intense reflections of hematite and goethite. These iron oxides are thought to be coating or acting as cement of particles to form mineral aggregates.

The XRD pattern (Figure 2c) and Mössbauer spectrum (Figure 3c) for the CVE sample after five sequential CBD treatments indicate that the preparation procedure was only partially effective to remove goethite, hematite and martitized magnetite. The decrease in intensities of hematite and goethite XRD reflections points to a better effectiveness of the CBD treatment on removing iron from $\mathrm{Fe}^{3+}$ rich minerals of the sample.

SEM images of the same sample show the predominance of magnetite, goethite, hematite, chromite and martitized magnetite. After CBD-treatment sample, observations show that there are a decrease of the number of grain associations containing hematite, goethite and martitized magnetite. The CBD treatment does not remove chromite but the value of the saturation magnetization $\left(81.3 \mathrm{~J} \mathrm{~T}^{-1} \mathrm{~kg}^{-1}\right)$ (Table 1) increases relatively to the untreated magnetically concentrated sample $\left(60.8 \mathrm{~J} \mathrm{~T}^{-1} \mathrm{~kg}^{-1}\right)$.

No significant difference was observed on the X-ray patterns of the untreated magnetic separate of the sample CVE (Figure 2b) when compared with that of the same

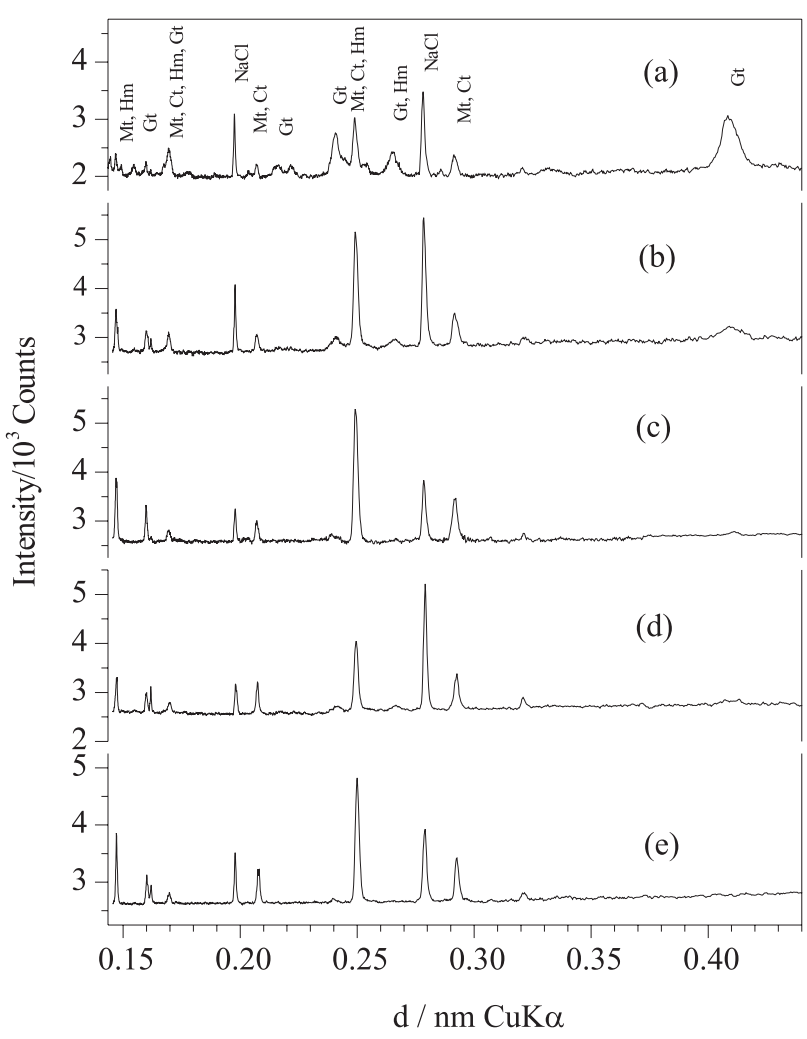

Figure 2. Powder X-ray patterns of the CVE. (a) whole sample; (b) magnetic fraction; after (c) five successive extractions with CBD; (d) $5 \mathrm{~mol} \mathrm{~L}^{-1} \mathrm{NaOH}$ concentration treatment and (e) $\mathrm{NaOH}$ and then CBD treatment, $\mathrm{Mt}=$ magnetite $; \mathrm{Hm}=$ hematite, $\mathrm{Gt}=$ goethite, $\mathrm{Ct}=$ chromite, $\mathrm{NaCl}=$ internal standard. 
sample treated with $5 \mathrm{~mol} \mathrm{~L}^{-1} \mathrm{NaOH}$ (Figure 2d). However, a noticeable change is observed when corresponding Mössbauer spectra are compared (Figures $3 \mathrm{~b}$ and 3d). The

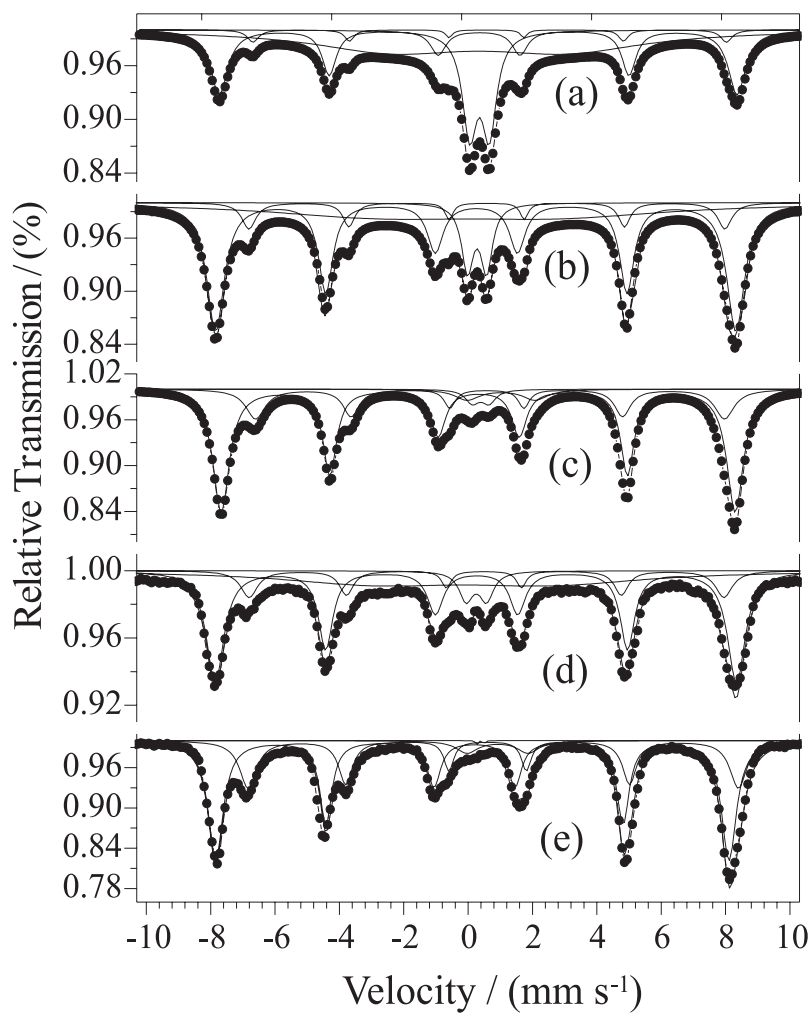

Figure 3. Room-temperature Mössbauer spectra ot the CVE (a) whole sample; (b) magnetic fraction; after (c) five successive extractions with $\mathrm{CBD}$; (d) $5 \mathrm{~mol} \mathrm{~L}^{-1} \mathrm{NaOH}$ concentration treatment and (e) $\mathrm{NaOH}$ and then $\mathrm{CBD}$. intensity of the central doublet is reduced indicating the removal of paramagnetic iron in silicates and possibly chromite. The value of the saturation magnetization (Table 1) of the sample treated with $5 \mathrm{~mol} \mathrm{~L}^{-1} \mathrm{NaOH}$ is now somewhat higher $\left(69.5 \mathrm{~J} \mathrm{~T}^{-1} \mathrm{~kg}^{-1}\right)$ than that of to the untreated magnetic separate $\left(60.8 \mathrm{~J} \mathrm{~T}^{-1} \mathrm{~kg}^{-1}\right)$, though smaller than that one of the CBD-treated sample $\left(81.3 \mathrm{~J} \mathrm{~T}^{-1} \mathrm{~kg}^{-1}\right)$.

The X-ray pattern of the sequentially treated magnetic separate $5 \mathrm{~mol} \mathrm{~L}^{-1} \mathrm{NaOH}$ and five extractions with $\mathrm{CBD}$ (Figure 2e) indicates that goethite was not totally removed from the sample. Corresponding Mössbauer spectrum (Figure 3e) shows a decrease of the central doublets and an increase of the relative area of the magnetic subspectrum relative to the spectrum for the untreated magnetic fraction (Figure 3b). Changes in saturation magnetization (Table 1) were found to be about $35 \%$ higher in the treated ( 84.4 $\left.\mathrm{J} \mathrm{T}^{-1} \mathrm{~kg}^{-1}\right)$ than in the untreated $\left(60.8 \mathrm{~J} \mathrm{~T}^{-1} \mathrm{~kg}^{-1}\right)$ sample. EDS data and SEM images of the treated sample show dominant existence of stoichiometric magnetite grains. The results suggest that practically all iron bearing minerals except stoichiometric magnetite are removed by $5 \mathrm{~mol} \mathrm{~L}^{-1} \mathrm{NaOH}$ treatment, followed by CBD treatment.

\section{SPN samples}

The in nature SPN sample is dark gray to black and it is also strongly magnetic. Typical morphologies of the particles are visualized by SEM (Figure 4). The optical microscopy analysis of its magnetic fraction confirms the occurrence mainly of martitized magnetite. Its X-ray pattern

Table 2. Mössbauer parameters of the samples (298 K); $\delta=$ isomer shift relative to $\alpha \mathrm{Fe} ; \varepsilon=$ quadrupole shift; $\mathrm{B}_{\mathrm{hf}}=$ hyperfine field; RA = relative area of the subspectrum; \{ \} and [ ] mean octahedral and tetrahedral sites, respectively. (a) whole sample, (b) magnetic fraction, (c) five successive extractions with $\mathrm{CBD}$, (d) $\mathrm{NaOH} 5 \mathrm{~mol} \mathrm{~L}^{-1}$ concentration treatment and (e) treated with $\mathrm{NaOH}$ and then whit CBD

\begin{tabular}{|c|c|c|c|c|c|}
\hline Samples & Site & $\delta / \mathrm{mm} \mathrm{s}^{-1}$ & $\varepsilon / \mathrm{mm} \mathrm{s}^{-1}$ & $\mathrm{~B}_{\mathrm{hf}} / \mathrm{T}$ & $\mathrm{RA} / \%$ \\
\hline \multirow[t]{2}{*}{ SPN (a) } & {$\left[\mathrm{Fe}^{3+}\right]$} & $0.278(1)$ & $-0.020(1)$ & $49.28(1)$ & $21.5(4)$ \\
\hline & $\left\{\mathrm{Fe}^{3+/ 2+}\right\}$ & $0.695(1)$ & $0.006(1)$ & $46.56(2)$ & $35.9(5)$ \\
\hline \multirow[t]{2}{*}{ SPN (b) } & {$\left[\mathrm{Fe}^{3+}\right]$} & $0.295(1)$ & $<0.01$ & $49.14(1)$ & $30.3(4)$ \\
\hline & $\left\{\mathrm{Fe}^{3+/ 2+}\right\}$ & $0.674(1)$ & $0.007(1)$ & $45.94(2)$ & $55.8(6)$ \\
\hline \multirow[t]{2}{*}{ SPN (c) } & {$\left[\mathrm{Fe}^{3+}\right]$} & $0.291(1)$ & $-0.003(3)$ & $49.14(1)$ & $30.2(4)$ \\
\hline & $\left\{\mathrm{Fe}^{3+/ 2+}\right\}$ & $0.675(1)$ & $0.003(1)$ & $46.02(4)$ & $56.5(6)$ \\
\hline \multirow[t]{2}{*}{ SPN (d) } & {$\left[\mathrm{Fe}^{3+}\right]$} & $0.292(3)$ & $-0.018(2)$ & $49.16(1)$ & $35.1(3)$ \\
\hline & $\left\{\mathrm{Fe}^{3+/ 2+}\right\}$ & $0.678(1)$ & $0.004(1)$ & $46.14(1)$ & $61.2(6)$ \\
\hline \multirow[t]{2}{*}{ SPN (e) } & {$\left[\mathrm{Fe}^{3+}\right]$} & $0.300(9)$ & $<0.01$ & $49.13(1)$ & $32.1(3)$ \\
\hline & $\left\{\mathrm{Fe}^{3+/ 2+}\right\}$ & $0.678(1)$ & $0.014(4)$ & $45.95(1)$ & $63.0(6)$ \\
\hline \multirow[t]{2}{*}{ CVE (a) } & {$\left[\mathrm{Fe}^{3+}\right]$} & $0.248(1)$ & $-0.029(1)$ & $50.40(1)$ & $30.5(4)$ \\
\hline & $\left\{\mathrm{Fe}^{3+/ 2+}\right\}$ & $0.644(1)$ & $0.103(1)$ & $46.08(4)$ & $4.2(1)$ \\
\hline \multirow[t]{2}{*}{ CVE (b) } & {$\left[\mathrm{Fe}^{3+}\right]$} & $0.246(3)$ & $-0.019(1)$ & $50.09(1)$ & $63.5(6)$ \\
\hline & $\left\{\mathrm{Fe}^{3+/ 2+}\right\}$ & $0.679(1)$ & $0.007(7)$ & $45.82(2)$ & $18.8(2)$ \\
\hline \multirow[t]{2}{*}{ CVE (c) } & {$\left[\mathrm{Fe}^{3+}\right]$} & $0.242(1)$ & $0.015(1)$ & $50.04(1)$ & $69.9(7)$ \\
\hline & $\left\{\mathrm{Fe}^{3+/ 2+}\right\}$ & $0.656(1)$ & $0.101(1)$ & $45.64(2)$ & $21.6(3)$ \\
\hline \multirow[t]{2}{*}{ CVE (d) } & {$\left[\mathrm{Fe}^{3+}\right]$} & $0.251(1)$ & $-0.024(1)$ & $50.20(1)$ & $51.5(5)$ \\
\hline & $\left\{\mathrm{Fe}^{3+/ 2+}\right\}$ & $0.632(1)$ & $0.081(1)$ & $45.71(3)$ & $12.9(1)$ \\
\hline \multirow[t]{2}{*}{ CVE (e) } & {$\left[\mathrm{Fe}^{3+}\right]$} & $0.200(1)$ & $-0.004(1)$ & $49.13(1)$ & $62.1(5)$ \\
\hline & $\left\{\mathrm{Fe}^{3+/ 2+}\right\}$ & $0.678(1)$ & $0.010(1)$ & $45.95(1)$ & $34.2(3)$ \\
\hline
\end{tabular}


reveals the presence of chromite and other iron-rich spinels (Figure 5a). Mössbauer data indicate the existence of magnetite (Figure 6a). No significant difference was observed on the X-ray patterns of the in nature SPN sample (Figure 5a). Mössbauer spectra (Figure 6b) and fitted parameters (Table 2) of the SPN magnetic separate point to some altered magnetite due to some $\mathrm{Fe}^{2+} \rightarrow \mathrm{Fe}^{3+}$ oxidation process, as confirmed by the optical patterns, even thought

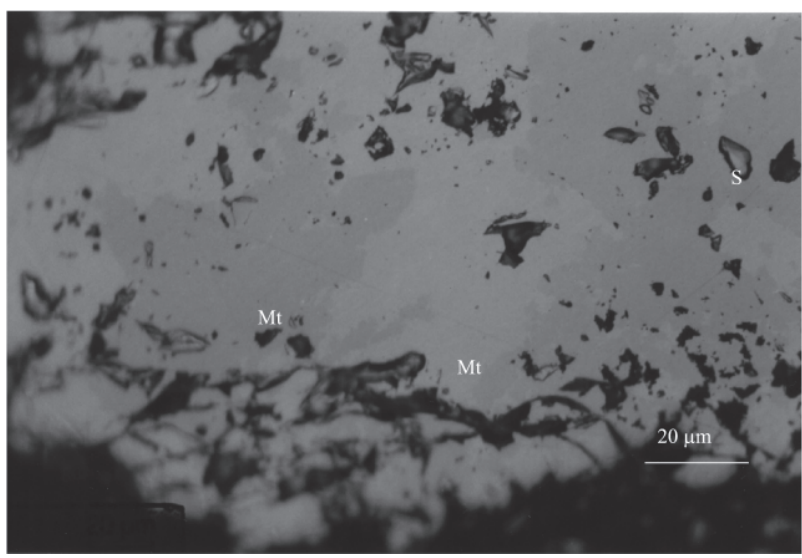

Figure 4. Electron micrograph of the magnetic fraction from the SPN sample. $\mathrm{Mt}=$ magnetite.

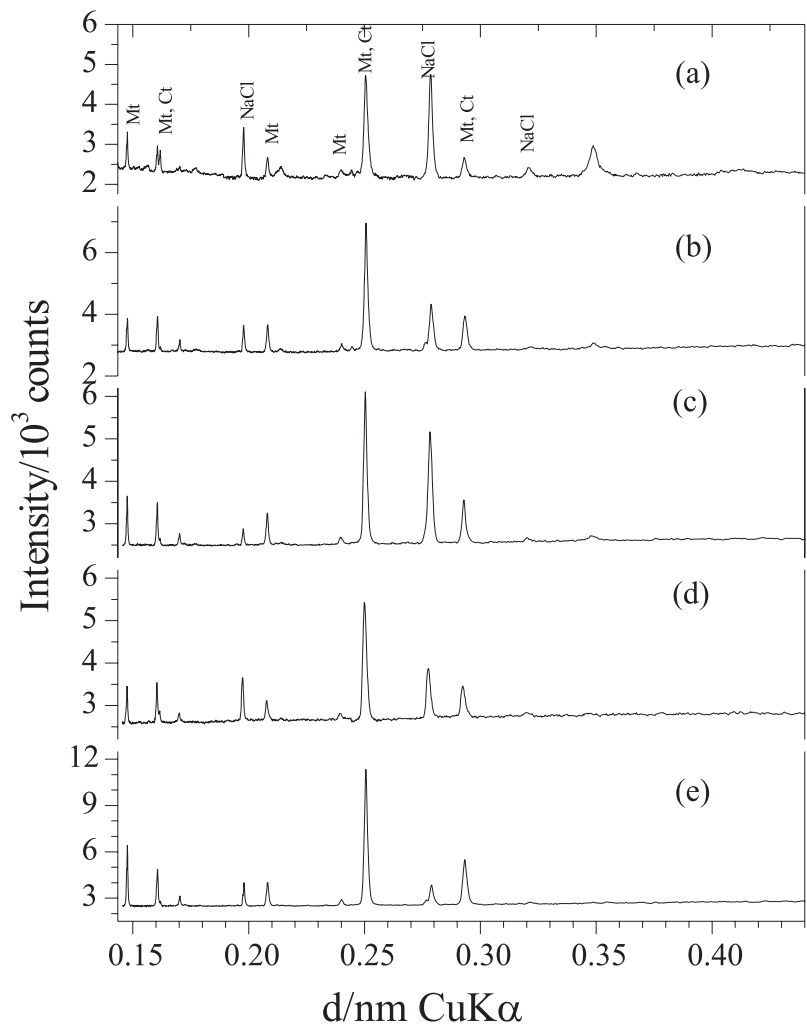

Figure 5. Powder X-ray patterns of the SPN. (a) whole sample; (b) magnetic fraction; after (c) five successive extractions with CBD; (d) $5 \mathrm{~mol} \mathrm{~L}^{-1} \mathrm{NaOH}$ concentration treatment and (e) $\mathrm{NaOH}$ and then $\mathrm{CBD}, \mathrm{Mt}=$ magnetite $\mathrm{Ct}=$ chromite, $\mathrm{NaCl}=$ internal standard.

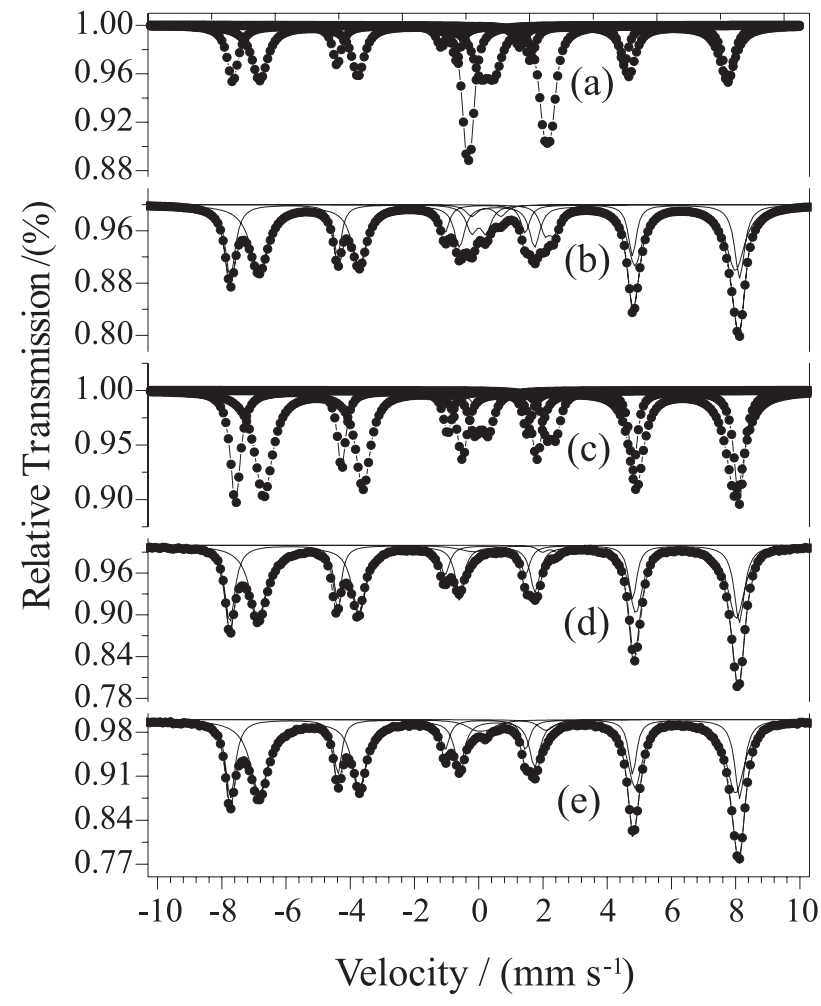

Figure 6. Room-temperature Mössbauer spectra of the SPN. (a) whole sample; (b) magnetic fraction; after (c) five successive extractions with CBD; (d) $5 \mathrm{~mol} \mathrm{~L}^{-1} \mathrm{NaOH}$ concentration treatment and (e) $\mathrm{NaOH}$ and then $\mathrm{CBD}$.

oxidation in this case seems to be less extensive than in sample CVE. The corresponding averaged chemical formulae for iron oxide spinels of the SPN sample can be derived from EDS data:

$\mathrm{Fe}_{1.91}^{3+} \mathrm{Fe}_{0.92}^{2+} \mathrm{Ni}_{0.02} \mathrm{Co}_{0.01} \mathrm{Si}_{0.01} \otimes_{0.13} \mathrm{O}_{4}$.

Mössbauer data indicate that the CBD treatment was effective to remove silicates and possibly chromite as it can be inferred from the reduced intensity of the central doublets, comparatively to that of the spectrum for the untreated sample.

The CBD treatment on the magnetic portion of SPN sample gives no essential difference on XRD (Figure 5c) or Mössbauer (Figure 6c) patterns, relatively to the untreated material (Figures $5 \mathrm{~b}$ and $6 \mathrm{~b}$ ). The situation is remarkably different with $\mathrm{NaOH}$ treatment. Changes in XRD and Mössbauer figures due to $\mathrm{NaOH}$ treatment (Figures 5d and 6d) on the SPN magnetic fraction are assumed to reflect removal of silicates and chromite. Changes in saturation magnetization (Table 1) values, i.e. $68.5 \mathrm{~J} \mathrm{~T}^{-1} \mathrm{~kg}^{-1}$ (before) to $85.8 \mathrm{~J} \mathrm{~T}^{-1} \mathrm{~kg}^{-1}$ after chemical treatment (Table 1), also indicate selective dissolution so to concentrate magnetic minerals. 


\section{Conclusions}

The purple hard material of the weathering mantle developing on peridotite of the mining area of Cerro Matoso, Colombia, does contain hematite, goethite, chromite and magnetite whereas the black saprolite of the same profile was found to contain only magnetite and chromite as the main iron-rich minerals.

X-ray diffractometry and Mössbauer spectroscopy data indicate that the selective chemical treatment with the mixture $\mathrm{CBD}$ and $\mathrm{NaOH}$ are very effective in removing hematite, goethite and other paramagnetic mineral phases. The decrease of the relative area of the central doublet relatively to the magnetic six-line pattern of Mössbauer spectra indicates removal of paramagnetic iron in silicates and chromite and proportionally concentration of magnetic minerals, particularly stoichiometric magnetite. The effectiveness of these treatments is also observed by the corresponding increase of the saturation magnetization values.

\section{Acknowledgements}

Work financially supported by CNPq, FAPEMIG and FINEP (Brazil).

\section{References}

1. Cornell, R. M.; Schwertmann, U.; The Iron Oxides (Structure, Properties, Reactions, Occurrence and Uses), Wiley-VCH: Weinheim, 2003, pp. 297, 664.

2. Mehra, O.P.; Jackson, M.L. In National Conference on Clays and Clay Minerals. 7. Proceedings; Swineford, A., ed., Pergamon Press : Washington, 1960, p. 317.
3. Norrish, K.; Taylor, R. M.; J. Soil Sci. 1961, 12, 294.

4. Kämpf, N., Schwertmann, U.; Clays Clay Miner. 1982, 30, 401.

5. Gonçalves, C.M.; Fabris, J.D.; Pacheco Serrano, W.A.; Hyperfine Interact. 1999, 122, 71.

6. Jackson, M.L. In Soil Chemical Analysis, Prentice-Hall: Englewood Cliffs, 1958, p. 498.

7. Schulze, D.G.; Dixon, J.B.; Soil Sci. Soc. Am. J. 1979, 43, 793.

8. Schulze, D.G. In Separation and Concentration of IronContaining Phases; Stucki, J.W.; Goodmann, B.A.; Schwertmann, U., eds. Dordrecht: Reidel, 1988, 63.

9. Goulart, A.T.; Jesus Filho, M.F.; Fabris, J.D.; Coey, J.M.D.; Phys. Chem. Miner. 1997, 25, 63.

10. Hunt, C. P.; Singer, M. J.; Kletetschka, G.; TenPas, J.; Verosub, K. L.; Earth Planet Sci. Lett. 1995, 130, 87.

11. Jeanroy, E.; Rajot, J. L.; Pillon, P.; Herbillon, A. J.; Geoderma 1991, 50, 79.

12. Singer, M. J.; Bowen, L.H.; Verosub, K.L.; Fine, P.; TenPas, J.; Clays Clay Miner. 1995, 43, 1.

13. Goulart, A. T.; de Jesus Filho, M. F.; Fabris, J. D.; Coey, J. M. D.; Phys. Chem. Miner. 1997, 25, 63.

14. Van Oorschot, I. H. M.; Dekkers, M. J.; Earth Planet. Sci. Lett. 1999, 167, 283.

15. Robertson, R. R.; Vargas, I. P. E.; MJ-Engineering Mining J. 1985, 186, 18 .

16. Fabris, J.D.; Coey, J.M.D.; Mussel, W. da N.; Hyperfine Interact. 1998, 113, 249.

17. Coey, J.M.D.; Cugat, O.; McCauley, J.; Fabris, J. D.; Revista de Física Aplicada e Instrumentação 1992, 7, 25.

Received: January 7, 2004 Published on the web: November 5, 2004 